\title{
„Stosowny sam w sobie" - czyli rzecz o reportażu radiowymi
}

Kinga Klimczak 


\section{Kinga Klimczak}

\section{„Stosowny sam w sobie” - czyli rzecz o reportażu radiowym}

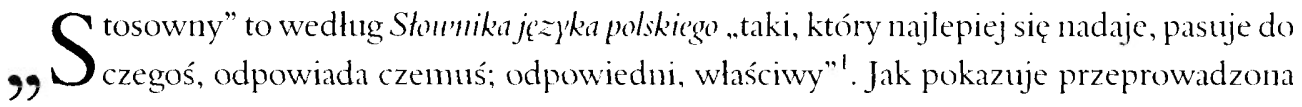
przeze mnie sonda, potoczne rozumienie tego wyrazu bliskie jest jego słownikowenu znaczeniu tylko wśród ludzi dorosłych. Z młodzieżowego zasobu słownictwa czynnego opozycja wyrazów „stosowny” - „niestosowny” powoli znika, a warunki i okoliczności, jakie wyrazy te określały pierwotnie, przez nastolatków nazywane są dziś jako "gafy" czy "wpadki”. W sytuacji, gdy starszy Polak użyje stowa ..stosowny”, mkodszy od niego o 30-40 lat powic po prostu: ,jest OK”. Gdybym zmontowala sondę ze wszystkich wypowiedzi, jakie uzyskałam, przeważałyby zdania w rodzaju: „nie wiem”, „nie mam pojęcia”. Wynika to jednak z trudności definiowania słów. Polacy mają bowiem świadomość istnienia zjawisk eleganckich i nieeleganckich, zgodnych i niezgodnym z przyjętymi zasadami życia w spoleczeństwie, a co się z tym wiąze - istnienia słów, określających tego rodzaju zjawiska.

Pojecie stosowności w reportażu radiowym funkcjonuje — zdaniem Janiny Jankowskiej — jako swoista „norma niepisana”. Istnieje zresztą od dawna, „od zawsze”, i istnieć powinno, ponieważ jest ściśle związane z etyką dziennikarską, z wrażliwością i moralnością człowieka mediów. I choć w środowisku reporterskim nie nadıżywa się na co dzień opozycyjnej pary wyrazów „stosowny” - ,niestosowny”, choć nie wyglasza się w związku z tym patetycznych deklaracji, to biegający po ulicacl z mikrofonem w ręku dziennikarz, którego zadaniem i celem jest nagrywanie dźwięków życia - w różnych jego przejawach: czasem radosnych, czasem tragicznych, ale zawsze autentycznych; pokazywanic wielkich ludzi, zwycięzców, i tych z marginesu, którzy przegrali swój los — dziennikarz taki wic, że istnieją normy życia spo- 
lecznego, jakich przekroczyć nie wolno, że są tematy, do których podejść należy z delikatnością, że jest granica stosowności, której naruszenie grozić może ludzką krzywdą.

Zakres pojęcia „stusowność” w reportażu radiowym zmienial się, a drogę tej ewolucji wyznaczała historia. Najważniejszym momentem było niewątpliwie przejście z ustroju komunistycznego na ścieżkę demokracji, a co za tym idzie - przeniesienie punktu ciężkości (nie tylko przecież w reportażu) z ogółu na jednostkę, powolne ksztaltowanie się szacunku (i umiejętności jego okazywania) dla pojedynczego czlowieka, przyzwolenie na swobodę i wolność jego wypowiedzi, poglądów, w konícu przyznanie mu pełnego prawa decydowania o sobie.

W okresie komunizmu reporter, któremu udało się zdobyć odpowiednie zezwolenie sądu, mógl nagrywać aresztowanie oskarżonego czlowieka, cały proces, wstrząsające zeznania. Sam oskarżony nie mial prawa decydowania o swoim losie, nikt nie pytał się go o zgodę na nagranie. Reportaż Janiny Jankowskiej Man dopiero 21 lat powstał właśnie w takich okolicznościach - na bazie materiahu zdobytego podczas procesu.

Czasem dziennikarz przekraczal świadomie normy uznane społecznie za obowiązujące, przekraczal granice ,.stosowności”. Jego działanie bylo usprawiedliwione tylko wówczas, gdy taka prowokacja miała na celı szczytne intencje, „wyższe cele”. Wspomnę tylko, że przekraczanie granic "stosowności” dla wyższych ideologicznie celów zdarzało się najczęściej w czasach komunizmu. Janina Jankowska, robiąc reportaże przed rokiem 1990, uważała, że jest uprawniona do nagrywania z ukrytego mikrofonu. Chciała udokumentować dla przyszlych pokoleń i pokizać sobie współczesnym p raw dę, a ta niestety była przez władze skrzętnie ukrywana. Podejrzewam, że w takiej właśnie atmosferze powstał reportaż Janiny Jankowskiej Polski Sierpień i zapewne też Ošzukani².

Okazją do konfrontowania sposobu postrzegania świata przez reporterów z różnych stron Europy (i nie tylko) były międzynarodowe festiwale twórczości radiowej. To wtedy, podczas ich trwania szczególnie wyraźnie okazywało się, że to, co zdaniem dziennikarzy ze wschodniej części Starego Kontynentu (w tym Polski) mieści się w granicach „stosowności”, dla reporterów z demokratycznej Europy Zachodniej jest absolutnie „niestosowne”, wręcz szokuje i oburza ${ }^{3}$. Podczas jednego z takich festiwali z bardzo negatywnymi emocjami spotkała się emisja reportażu, który został zmontowany na podstawie materiałów zarejestrowanych podczas aresztowania pewnego czlowieka, ale bez wyrażenia jego zgody na nagranie. Podobne wrażenie na dziennikarzach z Zachodu wywarl polski reportaż przedstawiający historię kobiety, która podczas wywabiania benzyną plamy z bluzki uległa silnemu poparzeniu, zwłaszcza twarzy. Kontrowersje wzbudzil jednak nie sam temat, ale sposób i okoliczności, w jakich material zostal zdobyty. Autorka dokonała wstrząsającego nagrania przypadkowo. Wracając z jakiegoś wywiadu w szpitalu, uslyszała w jednej z sal przeraźliwy krzyk tej właśnic

\footnotetext{
[J. Jankowska. Sztuka reportazu rudiourego. |w:] 70 lat Polskiego Radia. Warszawa 1995, s. 110.

"Por np. A. Schopenhaner. Enyst\}ka, czyli sztuka prou'adzemia sporón', th. B. i L. Konorscy, przedm. T. Kotar.

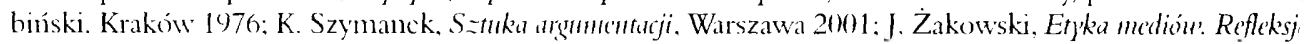
osobiste. [w:] Media i dicimikarstu'o u' Polsce 1989-1995. Kraków 1996, s. 202-211.
} 
poparzonej kobiety. Bez jej zgody zarejestrowała na taśmie odglosy cierpienia, które następnie wyemitowała w reportażu. Dziennikarka nie rozumiała oburzenia, z jakim został odebrany jej materiał. Uważała, ze w pełni spełnila swój reporterski obowiązek, zdobywając autentyczne, pełne emocji nagranie, które przecież porusza słuchacza. Wychowana w systemie kommistycznym i w charakterystycznej dla tantego okresu mentalności, nie rozumiała, ze istnieje - lub co najmniej winna istnieć - wartość najwyższa, czyli szacunek wobec pojedynczego czlowieka.

Przed dwudziestu, trzydziestu laty pomiędzy dziennikarzami ze wschodu i zachodu Europy istniała także różnica w pojmowaniu stosowności, dotycząca możliwości (bądź niemożności) uczynienia bohaterami nagrań członków rodziny i najbliższego środowiska. W Polsce nie robiono takich nagrań, uważając je za przykład swoistego ekshibicjonizmu. Domownicy, rodzina, jej problemy, troski - byly dla reporterów z naszego kraju czymś w rodzaju tematów tabu. Wszelką prywatność pozyskiwano z „obcego źródła”. Głębokich wyznań dokonywali przed polskim mikrofonem ludzie niezwiązani blisko z reporterem, który ten mikrofon trzymal. Na Zachodzie - przeciwnie. Tu tematów (często kontrowersyjnych i wymagających od rozmówcy emocjonalnego ekshibicjonizmu) szukano w najhliższym otoczeniu. Bacznie obserwowano relacje między znajomymi małżonkami, rozmawiano na trudne tematy z rodzicami i dziećmi z sąsiedztwa, opisywano tragedie ,z własnego podwórka”. Przyczyn takiego stanu rzeczy upatruje Janina Jankowska (moim zdaniem trafnie) między innymi w tym, że polscy dziennikarze zawsze mieli dużą odwage pytania swoich rozmówców o sprawy bardzo intymne. Ich zachodnim kolegom znacznie trudniej przychodziło pozyskiwanie wyznań, prywatnego, delikatnego materiałı. Jeśli sięgali do sfery intymnej, to do tej „ze swego terenu”, rodzinnego środowiska, bo tu można było zadawać pytania najlatwiej i najbezpiecznicj. Być może powodem tego, że pokazywanie sfery prywatnej szerokiemu gronu adresatów (w przeważającej większości ludzion obcym i anonimowym) uważali Polacy za rzecz „niestosowną”, bylo także wychowanie w duchu i mentalności minionego systemu? Wszystko, co intymne, osobiste i jednostkowe, stanowiło prywatną sprawę człowieka, a obnażanie tych sfer po prostu budzilo strach.

Z czasem, wraz ze zmianami polityczno-spolecznymi, ewoluował w polskim reportażu radiowym zakres słowa "stosownośc”. Nadanie praw pojedynczemu obywatelowi, przeniesienie punktu ciężkości ze spoleczeństwa na jednostkę i jej indywidualną godność, wiązało się ze zmianami w etyce dziennikarskicj, w sposobie pozyskiwania materialu dźwiçkowego, w końcu sprowadzało się też do różnicy stosunku dziennikarza do „nagrywanego" przez niego czlowicka. Dziś nie rejestruje się na taśmie wyznań ludzi w tragiczuych sytuacjach, w czasie agonii czy aresztowań, bez ich zgody na ową rejestrację. I co ważniejsze - nie ma zgody prawnej na emitowanie na antenie reportażu zawierającego nagrania, na które nie uzyskano pozwolenia. Natomiast dziś bohaterami czyni się swoich bliskich. Najwyraźniej mniej wstydzimy się swojej prywatności.

Obecuie na antenie radiowej reportaz zajmuje coraz muiej micjsca. Mowa oczywiście o radiu publicznym, bo w komercyjnym tego rodzaju twórczość nie ma w ogóle racji bytu. 
Ważny zaś punkt w codziennym rozkładzie programów, i to zarówno w stacjach publicznych, jak niepublicznych, stanowi publicystyka, poranne rozmowy z politykami, wywiady ${ }^{+}$na najważniejsze w danym czasie i często bardzo kontrowersyjne tematy. Warto w tym miejscu zastanowić się nad wspólcześnie obserwowaną relacją dziennikarz — rozmówca i dziennikarz (nadawca) - shuchacz (odbiorca) ${ }^{5}$ w radiowym dyskursie publicznym i w reportażu radiowym, i jednocześnie nad stosownością każdej z tych relacji. Nie sposób oczywiście ściśle porównywać z sobą tych dwóch rodzajów dziennikarskiej pracy, wraz z charakterystycznymi dla nich sposobami nawiązywania kontaktu z rozmówcą lub ze sluchaczem, czy też właściwych im środków wyrazu. Inıych zachowań oczekuje się od twórcy reportażu, innych od prowadzącego dyskusje publiczną dziennikarza". Chodzi raczej o przeanalizowanie, na ile każda z tych relacji (oddzielnie w dyskursie, oddzielnie w reportażu) jest „stosowna” z osobna, na ile wykorzystuje możliwą dla siebie skalę „wlaściwych” zachowań. Zarówno od dziennikarza-publicysty, jak od dziennikarza-reportera sluchacz znajdujący się po drugiej stronie odbiornika, niezależnie od swojego wyksztalcenia i pozycji społecznej, domaga się okazania należnego sobie szacunku.

Przyshuchując się wspólczesnemu dyskursowi publicznemu i próbując wydobyć z niego najważniejsze cechy w zakresie interesujących nas tu zagadnień, skupilam się glównie na poramnych rozmowach Jolanty Pieńkowskiej w trzecim programie Polskiego Radia oraz (w rozgłośniach komercyjnych) Doroty Gawryluk w Tok FM i Moniki Olejnik w Radiu Zet.

Rozmowy publicystyczne charakteryzuje bardzo mały (by nie powiedzieć żaden) dystans pomiędzy redaktorem a jego rozmówcą, najczęściej politykiem. Taka dyskusja nie ma jednak wymiaru partnerskiego. Dziennikarz jest często stroną atakującą, agresywną, niekiedy natarczywie i zuchwale przerywa, wtrąca swoje zdanie ${ }^{7}$. A jeśli rozmówca nie pozostaje mu dłużny, dyskurs ten - z założenia publiczny — staje się niemal walką na ringu, podczas której, sku-

\footnotetext{
+ Wywiad jako osobny gatumck radiowy wymagalby oczywiścic odrçbnego omówicnia. O ile, jak sądzę, problem reportażu radiowego w znacznym stopniu uporządkowala E. Pleszkun-Olcjniczakowa w tekście opublikowanym w materialach seminaryjnych z Kazimierza Dolnego (200)3), o tyle brak pracy w miarę zwiçźle omawiającej wywiad i rozmowę radiową, wyposażoncj i stosowną bibliografiç. Tymczasowo można wskazać kilka prac ugólnych: W. Furman. A. Kaliszewski. K. Wolny, Gutunki dziennikarskie. Specyfiku ith tu'orzeniu i redagou'a-

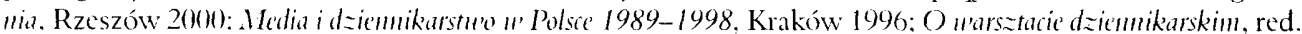

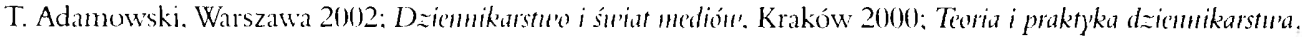
Warszawa 1964: M. Szulczewski, Publicyst)ka i u'spótc-e'snośc. Warszawa 1969. Na temat wywiadu, lecz wylącz-

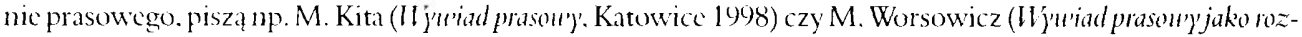
mou'd "ur roli". [w:] Tekst u' mediach. Eódź 200)2, s. 387-397).

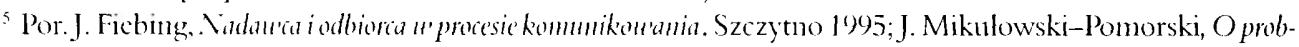
lemie tak =u'anci skuterzmośi medion", ..Przckazy i Opinic" 1989 nr 3-4. s. 15-42.

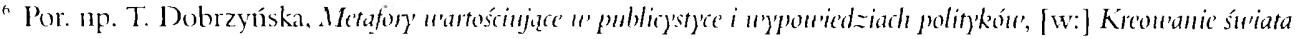

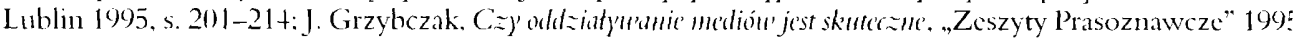
nr 3-4. s. 17-39: J. Mikulowski-Pomorski. Z. Nęcki, Kommmikoumanic skintezane?. Kraków 1993.

Oczywistym i od dawna znanym jest fakt. iz wywiad możc być - i rzecz jasna bywa - takze sposobem ryso wania własncgo wizerunku przez polityka. Por. np. M. Dawidziak-Kladoczna. Autoprezentacja " "'yuiadaci

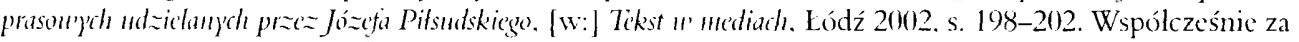

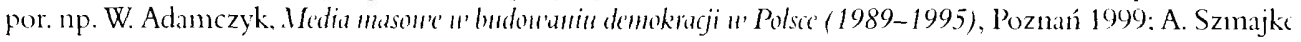
Antoprezentacka. Maski, pozy, minj'. Olsztyn 1999.
} 
piając się na wzajemnej szybkiej wymianie ostrych zdań, siedzący przy mikrofonach w studiu dysputanci zdają się zapominać o obecności shuchaczy. Obie strony ..tapią się za słówka”, rozmówcy bywają wobec siebie złośliwi i ironiczni - co wyrażają międ zy innymi przez intonację glosu i odpowiednie akcenty zdaniowe. Zdarza się, że dziennikarz przerywa swemu adwersarzowi po to, by powiedzieć to samo, co ten właśnie zaczął mówić, puentuje tylko calą kwestię jeszcze jakimś ostrzejszym wyrażeniem. Bywa i tak, że redaktor celowo podgrzewa atmosferę, prowokuje (najczęściej polityka) do „wyrzucenia” swych emocji (najlepiej jak najbardziej negatywnych pod czyimś konkretnyın adresem!) ${ }^{x}$.

Najbardziej na tej „bojowej atmosferze” podezas debat publicznych z politykami traci shuchacz, który po wyglaszanym na początku andycji przez niektórych dziennikarzy zwrocie „moim i państwa gościem” lub „naszym gościem był...” (zwrocie, który zakłada jednak obecność jakiejś „publiczności”), może mieć wrażenie, że calkowicie się o nim zapomina, a cala rozmowa odbywa się nie dla niego i poza możliwościami jego percepcji. Rzadko się bowiem zdarza, aby dziennikarz, który podczas dwunastı-piętnastı minut rozmowy porusza wiele tematów, często je zmienia, przerywa wątek i zaczyna następny, wyjaśniał odbiorcy wszelkie zawiłości polityczne, przypominal i krótko prezentowal zdarzenia, do jakich nawiązuje, tak aby człowiek przy głośniku mógł zorientować się w omawianym natłoku problemów i czegoś treściwego z audycji się dowiedzieć. Czasem wydaje się, że założeniem dziennikarza jest to, iż słuchacz wszystko wie albo (co gorsza) rozumić wszystkiego nic musi.

Inną znaczącą kwestią w omawianiu relacji nadawca (dziennikarz) — odbiorca (shuchacz) jest fakt, że podczas dyskursów publicznych mało jest pytaú o meritum, pytaní, które wyjaśniłyby istotne, acz zawiłe kwestie, pytań odważnych i konkretnych. Mówi się dużo i szybko, ale często jakby „obok” problemów, nie docierając do ich sedna. Bywa też tak, ze trudne, drążące zawiłości pytania są wprawdzie przez dziennikarza zadawane, ale brak na nie odpowiedzi, ponieważ uchylają się od nich politycy. Uciekają w wygodne dla siebie tematy, powtarzają kilka razy to samo zdanie, irytując swym zachowaniem i redaktora, i słuchacza, który, nie mogąc doczekać się upragnionej riposty, zniecierpliwiony, czasem po prostu wyłącza radio.

Wspólczesne dyskursy publiczne, przypominające walkę dwóch zamkniętych w studiu osób, izolują słuchaczy, powodują frustrację spoleczną. Przysłuchując się audycji, która dzieje się poza nim, odbiorca czuje się niepotrzebny, niezaangażowany w sprawy kraju, ma świadomość swej bezradności i poczucie, że się go ignoruje. Takie rozmowy mogą wzbudzać w spoleczeństwie agresję i złość, ukazıjąc, że nawet ludzie reprezentujący nas ma arenie międzynarodowej, ludzie dbający o nasze bezpieczeństwo, nie potrafią spokojnie rozmawiać, a świat polityki jest nieuporządkowany i pełen przemocy. Odbiorcy takiego dyskursu stają się świad-

\footnotetext{
${ }^{8}$ Przykładem niech będzic fragment rozmowy Moniki Olejnik z Lechem Kaczyńskim z 18 września 2(10)4, dotyczącej miçdzy innymi konfliktu prezydenta Warszawy z Micczyslawem Wachowskim. W jej trakcie Kaczyíski dość spokojnie, acz ironicznie wypowiadal siç na temat swego przeciwnika. Na koniec rozmowy uslyszal z ust redaktor Olcjnik slowa: ..Mieczyslaw Wachowski mówi: "No dobrze. żeby [pan] stracil stanowisko prezydenta, bo Kaczyński jest nieudacznikicmı". Po czym slychać śmich dzicnnikarki.
} 
kami spektaklu, który rozgrywa się poza nimi. A takiej relacji ze słuchaczem uznać za „stosowną" nie możemy.

Dobry reportaż jest specyficznym rodzajem twórczości radiowej, rzec można — ,jest stosowny samym w sobie”. Owa „stosownośc” realizuje się na dwóch płaszczyznach, w relacjach: dziennikarz - bohater nagrania oraz dziennikarz - shuchacz. Reportaż radiowy przede wszystkim, uwzględniając wynikającą z lıdzkiej natury potrzebę szczególowego wypowiedzenia się, daje człowiekowi możliwość zabrania głosu w omawianej materii, przybliżenia innym siebie i swoich spraw. Wzruszającym i pięknym przykładem opowiedzenia ludzkich losów poprzez reportaż i dzięki niemu może być Cźtou'iek z bandura Janiny Jankowskiej. Jest to historia spotkanego w Kijowie przez autorkę pieśniarza, który grą na tradycyjnym ukraińskim instsrumencie i śpiewem zarabia na życie, praca ta zaś daje mu ogromną radość. Bard wyśpiewuje słuchaczowi swoją opowieść o rodzinie i dzieciństwie, słowem i muzyką wyznaje milość do Ukrainy, nuci pieśń specjalnie dla nas - Polaków. A reporterka pozwala mu mówić, a właściwie śpiewać, o czym chce i ile chce. Czasem tylko, z uwagi na słuchacza, któremu mogą być obce przedstawiane przez „człowieka z bandurą” zdarzenia i momenty historyczne, dopowiada i wyjaśnia. Imnym razem, odwołując się do wyobraźni plastycznej odbiorcy, maluje obraz okolicy, w której spotkala barda, aby reportaż był całością, petnym obrazem, aby słuchacz z latwością mógł wyobrazić sobie owo magiczne miejsce w centrum Kijowa:

Siedzi na stoleczku u stóp zamkniętej cerkwi w wysokiej baraniej czapce. Siwa broda ukrywa wiek. Nad nim wznosza się przepyszne cerkiewne kopuly, zdobiące najpiç̧niejszy zakątek Kijowa (...). Na schodach otwarty futerał, do którego przechodnie wrzucają pieniądze. I Ionorarium trubadura losu ukraińskicgo.

Partnerską, wręcz „koleżeńską” relację między autorką reportażu a jej bohaterem, można zaobserwować też w reportażu Beż̇alı - opowieści o Janie Kelusie. Relacja ta nie jest niczym zaskakującym, zważywszy fakt, że dziennikarka zna osobiście barda „Solidarności”. Ważne jest jednak to, ze ten przyjacielski nastrój wytworzony został niejako dla słachacza. Zwroty: „wiesz”, ,pamiętasz”, zaśmiania się, potakiwania, szczekanie psa - wszystko to tworzy klimat dla snucia opowieści o nieprzeciçtnym czlowieku, o powiązaniu jego losów z historią narodu, klimat dla wyznań kogoś, kto śpiewem angażowal się w walkę polityczną. Partherski nastrój stworzony został nie tylko po to, by dwoje ludzi mogło powspominać dawne czasy, porozmawiać o wspólnych doświadczeniach, ale po to, by coś z tej opowieści wziął także kitoś trzeci - stuchacz.

Przykladem postawy szacunku, wyrażanego w sposobie prowadzenia rozmowy z bohate rem reportażu (wspomaganego także kompozycją andycji), jest reportaż Tenor. To opowieś o człowieku, który, doszedlszy kiedyś do finahu programu telewizyjnego Progi kariery, wiąza z tym faktem nadzieje na sławę i pieniądze. Niestety, po programie nie zgłosil się nikt, kto ze chcialby zainwestować w jego glos. „Tenor”, który określa się sam jako przystojny i utalento wany mężczyzna (jest przy tym niezwykle zabawny), pośrednio oskarża autorów program 
i biorących w nim udział sędziów o zmannowanie tak wielkiego i obiecującego talentu, którym jest wlaśnie on. Drugin rozmówcą redaktor Jankowskicj w tym reportażu jest Włodzimierz Korcz, jeden z dwunastu ekspertów, którzy oceniali występ ,tenora”. Autorka konfrontuje ich wypowiedzi, ,spotyka ich dla siebie” po raz drugi, aby mogli wyjaśnić powstalą sytıację. Każdego z nich traktuje tak samo, każdemu zadaje trudne pytania.

[Do W. Korcza:] Czy państwo zdawali sobie sprawę, że ci ludzie (...), którzy prezentowali swoje uniejęctności, którzy śpiewali, którzy brali udział w programie, łączyli z tym faktem wielkie nadzicje na przyszłość?

[Do „tenora”, który skarży się, że nie znalazł się sponsor i nic pomógł nnu wydać płyty:] A nie mógl pan sam zebrać pieniędzy gdzieś indziej zarobionych i sann nagrać?

Bohater - tenor, niegrzeszący skromnością, ośmiesza się (oczywiście nieświadom tego), jednak na tle całego reportażu nie jest postacią przejaskrawioną. Autorka traktuje go, mimo jego śmiesznostek, z szacunkiem, ale uświadamia mu też, że niezrealizowanie marzeń artystycznych to również wina samego tenora. Rzecz piękna i „stosowna”: na końcu reportażu sam ekspert docenia talent tenora, stwierdzając tylko, że nie czas dziś na takie glosy.

Reportaż radiowy jest gatunkiem bardzo bliskim emocjonalnie słuchaczowi. Tu prawdziwi ludzie, językiem barwnym, żywym i pełnym ekspresji, opowiadają swoje historie innym ludziom. Tu dokumentuje się prawdę historyczną środkami wyrazu właściwymi radiu, budıje się nastrój minionych wydarzeń, by mogły go przeżyć następne pokolenia. Tu — poszukując autentyzmu - wchodzi się w sam środek problemu, w jego meritum. I jeśli stosowności w radiu szukać w relacji dziennikarza z słuchaczem, rozmówcą czy bohaterem audycji, to w reportażu znajdziemy ją na pewno.

Reportaż radiowy przeszedl dhugą droge "techniczncj ewolucji”" — od literackiego (pisanego), odczytywanego lub tworzonego na żywo przed mikrofonem w studiu, poprzez włączanie krótkich materialów dźwiękowych z życia, aż do całkowitego zwycięstwa autentyzmu - czyli wyjścia dziennikarza z mikrofonem na ulicę, by tam zdobyć pełny materiał, a następnie opracować go do montażu z użyciem komputera. Na przestrzeni prawie pięćdziesięciu lat różne też były tematy, które najbardziej reporterów interesowały. Pojawiały się odmienne tendencje eksponowania samego dziennikarza w jego dziele. Niektórzy starali się całkowicie ukryć reportera i jego głos, inui - jak Jacek Stwora ${ }^{10}$ - uczynili narrację autorską kluczowym elementem utworu" ". Reportaż zmienial się i ciągle się zmienia. Ewolucji też ulegało pojecie „stosowności” w reportażu. Porówuıjąc jednak ten rodzaj twórczości radiowej

\footnotetext{
"Por. M. Kubica. Krótkic formy reporterskic u' Polskim Rudio. Warszawa 1971.

${ }^{11}$ Ku czci Jacka Stwory zorganizowano w bicżącym roku w Kazimicrzu Dolnym dziesiąty już konkurs reportażu radiowego jego inicnia. Pomysłodawezynią konkursu jest Janina Jankowska. która za tę inicjatywę otrzymała na festiwalu radiowym Prix Enropa w Bcrlinic w 1998 roku wyróżnicnic w kategorii pomysłów medialnych (Market Place of Ldeas).

"Por J. Jankowska, Szmk ra rerta $\approx$...
} 
choćby z analizowanymi tu rozmowami publicystycznymi, stwierdzić można, że „stosowność” jest nadrzędną cechą dobrego reportażu. „Stosowny” jest on dzięki spokojowi, jaki wnosi w medialny chaos oraz w ludzkie życie; dzięki temu, jak o tym życiu opowiada w piękny, barwny, autentyczny sposób — i z jakim odnosi się do niego szacunkiem. Jak ujęła to Janina Jankowska:

Wielki reportaż zmuszal odbiorcę do namysłu nad ludzka egzystencją, wyostrza jego percepcję świata ${ }^{12}$. 